\title{
Evaluation and Validation of Characterization Methods for Fatigue Performance of Asphalt Mixes for Western Australia
}

\author{
Ainalem Nega ${ }^{1, \text { a }}$, Hamid Nikraz ${ }^{2, \mathrm{~b}}$, Colin Leek $^{3, \mathrm{c}}$ and Behzad Ghadimi ${ }^{4, \mathrm{~d}}$ \\ ${ }^{1}$ PhD Candidate, Department of Civil Engineering, Curtin University, GPO Box U1987, Perth, WA 6845, Australia \\ ${ }^{2}$ Professor, Head of Department of Civil Engineering, Curtin University, GPO Box U1987, Perth, WA 6845, Australia \\ ${ }^{3}$ Adjunct Professor, Department of Civil Engineering, Curtin University, GPO Box U1987, Perth, WA 6845, Australia \\ ${ }^{4}$ PhD Candidate, Department of Civil Engineering, Curtin University, GPO Box U1987, Perth, WA 6845, Australia \\ a Ainalem.Nega@curtin.edu.au, ${ }^{\text {b }}$ H.Nikraz@ $@$ curtin.edu.au,${ }^{\mathrm{c}}$ C.Leek@ curtin.edu.au , \\ ${ }^{\mathrm{d}}$ Behzad.Ghadimi@ postgrad.curtin.edu.au
}

\begin{abstract}
The determination of appropriate pavement thickness using laboratory determined parameters is one of the key issues facing the road manager. Five different types of asphalt mixes were produced in laboratory to modify pavement performance mixture. The main objective of this study is to evaluate the characterization methods for fatigue performance of asphalt mixes to Western Australia road. In this study, laboratory test for indirect tensile modulus, dynamic creep, wheel tracking and aggregate gradation tests were taken to analyze each asphalt mixtures for a design traffic road. The results and analysis showed that AC20-75 asphalt mix blow is the most effective and efficient in pavement performance than the other asphalt mixes. AC14-75 was the second in rank to strengthen and durability of asphalt pavement. All asphalt mixes in this study can be used to strength and stable the overall stiffness of pavement, and modification rank can be described as AC20-75 Blow > AC14-75 Blow > AC14-50 Blow > AC7-50 Blow > SMA7-50 Blow in this research.
\end{abstract}

Author keywords: Pavement performance; asphalt mixture; characterization; indirect tensile modulus; dynamic creep; wheel tracking; aggregate gradation; Western Australia

\section{Introduction}

Around the world, demand for new asphalt pavement is increasing and lack of quantitative information on the long term field performance of asphalt mixes with conventional and other binder types, lack of quantitative information in the deformation of the appropriate pavement thickness and development of long term performance assessment of hot-mix asphalt thermal properties compaction using laboratory and field investigation is one of the key issues facing the main road and asphalt plant manager [1].

High demand for new asphalt pavement often requires that paving be done unfavourable construction conditions. For example, Low air temperatures, high winds, and night construction create adverse conditions for hot-mix asphalt paving [2]. This presents a risk for road owners and contractors. To achieve optimum load-bearing and weathering characteristics, an asphalt mix must be compacted to a specific range of density, and the time required for hot-mix asphalt to reach the proper compaction temperature to achieve this density decreases with an increased rate of cooling [2].

The difference between laboratory and in-service pavement fatigue lives is attributed a difference into loading condition, vehicle types and axle configuration, rest between vehicle load (effects of residual stresses and healing), traffic distribution (mixed traffic effect), vehicle wander, difference in mix compaction levels achieved and environmental factors such as seasonal temperature variation and temperature gradients that occur in the pavement.

To account for these differences, transfer functions or 'shift factor' are applied to derive predication of in-serve performance. As mentioned by several researchers and universities scholars, the magnitude of the shift factor is generally between 10 and 20 [1-6] depending on the perceived level 
of cracking in the pavement that could be tolerated. However, there is a strong need for further investigation, initially through a detailed laboratory characterization of indigenous asphalt mixes with conventional, multigrade and modified binders of the effect of volumetric properties, rest period, healing, and ageing, and multi-axle loading effects on fatigue performance $[1,5]$. There is a lack of quantitative information on the long - term field performance of asphalt mixes with conventional and other binder types. This information would assist in the estimate of shift factor and in the deformation of the appropriate pavement thickness.

The aim of this research is to evaluate the performance characteristics of the main mixes supplied to Mainroads Western Australia in terms of fatigue and deformation resistance, so that these data can be used to predicting thickness requirements for heavy duty pavements. Figure 1 shows a specimen in different types of testing equipment.

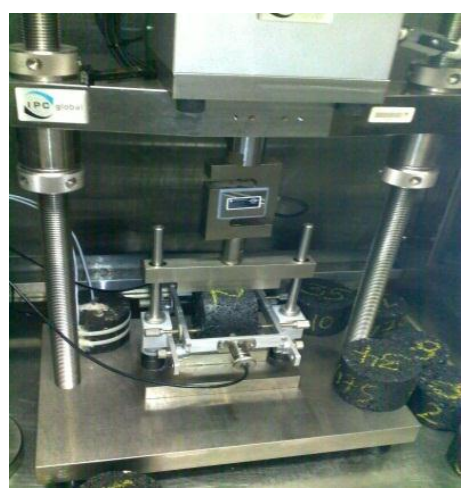

(a) Dynamic creep test

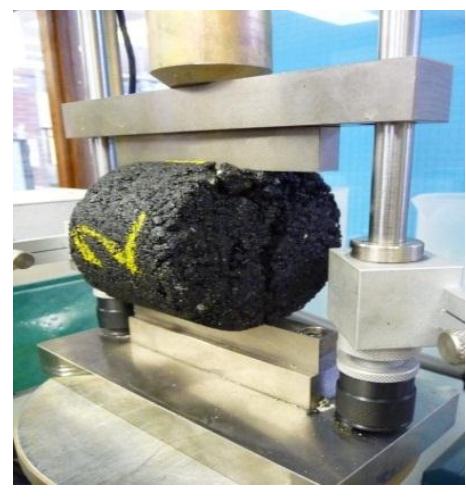

(b) Indirect tensile test

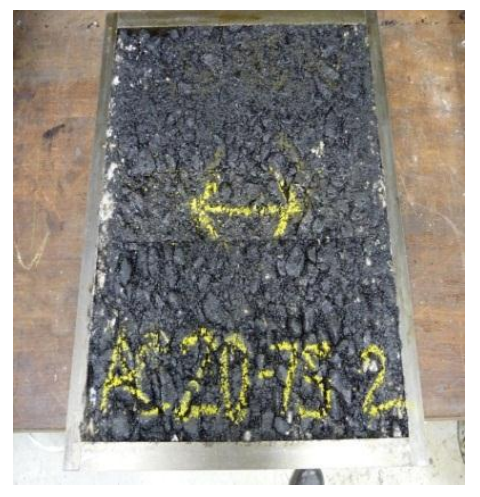

(c) Wheel tracking test

Figure 1: Specimens in Different Types of Testing Equipment

\section{Materials and Methods}

\subsection{Materials}

Types of hot mixed asphalt used on the Mainroads Western Australia (WA) network are dense graded asphalt (DGA), open graded asphalt (OGA) and stone mastic asphalt (SMA). DGA, the most common type of asphalt, provides optimal structure strength and generally good resistance to deformation. OGA is designed to drain water through the asphalt to remove excess water from the tyre/road surface. SMA is similar to OGA but has a high proportion of dust and high binder contents to achieve an improved fatigue life. SMA has a texture surface but does not drain water through its layer as does OGA [7-9]. All Materials selected for this project were from local sources and are indigenous of Western Australian pavement materials used in the industry.

\subsection{Methods}

The design method specified by Mainroads Western Australia is the Marshall method of mix design. The aim of the method is to satisfy specified design criteria. The descriptions of asphalt mixes design are as following:

- SMA7-50 blow: thickness of $7 \mathrm{~mm}$ granite stone mastic asphalt (SMA)

- AC7-50 blow: thickness of $7 \mathrm{~mm}$ open graded granite

- AC14-50 blow: thickness of $14 \mathrm{~mm}$ dense graded granite (intersection mix)

- AC14-75 blow: thickness of $14 \mathrm{~mm}$ dense graded granite (intermediate mix)

- AC20-75 blow: thickness of $20 \mathrm{~mm}$ dense graded granite (intermediate mix) 
In order to assess the evaluation and validation of characterization methods for fatigue performance of different types of asphalt mixture, it was necessary to obtain laboratory data on individual asphalt mixtures. During an individual asphalt mixes run, specimen was taken and assessed in different categories of asphalt mixes. Laboratory asphalt mix specimens were subjected to the following characterization tests: resilient modulus, dynamic creep, wheel tracking, and aggregate gradations test.

After samples had cooled to room temperature, bulk density and maximum specific gravity were performed according to the Australian Standard Test Method, AS 2891 from the local sources and indigenous of Western Australia roads. Air voids were calculated using bulk specific gravity and maximum theoretical specific gravity data. Five specimens to each asphalt mixes were tested as per AS 2891 and AG: PT/T231 [10-12]. Absorption values have been determined from presaturation testing using five masses and applied to the other four tests. The details methods of sampling and testing of hot-mix asphalt in Australian Standard Testing Method are shown in Table 1.

Table 1: Methods of Sampling and Testing Asphalt in Australian Standard Test Method [10-12]

\begin{tabular}{|c|c|}
\hline Material Test & Test Method \\
\hline $\begin{array}{c}\text { Resilient modulus } \\
\text { (Indirect tensile test method) }\end{array}$ & AS 2891.13.1 \\
\hline Dynamic creep & AS 2891.12.1 \\
\hline Wheel tracking & AGPT/T231 \\
\hline Aggregate gradations & AS 2891.3 \\
\hline
\end{tabular}

\section{Characterization Methods for Fatigue Performance of Asphalt Mixes}

\subsection{Indirect tensile modulus (resilient modulus)}

Resilient modulus of pavement material is an important material property in any mechanistically based design/analysis procedure for flexible pavements [13]. The resilient modulus $\left(M_{R}\right)$ is the material property required for the 1993 American Association of State Highway and Transportation Officials (AASHTO) Design Guide, which is an empirically based design procedure, and is the primary material input parameter for the 2002 Design Guide [14]. Several types of moduli have been used to represent the stiffness of asphalt concrete mixture. Three of these are dynamic, resilient, and complex. The Modulus of Resilient is most commonly used for asphalt concrete mixture evaluation [15].

\subsection{Dynamic creep}

Rutting is one of the predominant types of distress observed in hot-mix asphalt. Mallick, Ahlrich and Brown [16] used a dynamic creep to predict rutting. To evaluate the potential of dynamic creep, test were conducted on mixes of different aggregates and aggregate graduations to identify mixes with rutting potential. From the results that were obtained, there were a good correlation between permanent creep stain and rutting rates of pavements. The dynamic creep test was able to quantify the effect of aggregate type and graduation on rutting potentials of the mixes [16]. Mixes with crushed aggregate performed better in the creep test than the mixes with uncrushed aggregate.

\subsection{Wheel tracking}

Australia initially adopted the dynamic creep test as the preferred method of determining the rut resistance of asphalt mixtures. The test was simple to operate and test specimens were simple to compact in the laboratory or obtain by coring from existing pavements [12,17]. Wheel tracking was selected as the most suitable test method for measuring the rut resistance of asphalt mixtures. Olive and Alderson [18] indicated that the test had been shown to correlate well with rutting of roads in- 
service. The present standard in use in Australia is an Austroads test method (AG: PT/T231) that permit to determine the characteristic of wheel tracking test for both laboratory and field asphalt mixes [12].

\subsection{Aggregate gradation}

The fatigue life of asphalt concrete mixture is influenced by several factors such as bitumen type, binder content, and air voids content and other factors such as temperature, frequency and resting period of applied load. Although the influence of binder type and voids contents has been extensively studied, the effect of some aggregate properties such as the aggregate gradation has not been widely presented. Goetz [19] noted that the important role of aggregate gradation was recognized from the earliest days of asphalt mixture design.

Aggregate type and graduation are routinely considered in hot-mix asphalt (HMA) design. The line between aggregate gradation and asphalt mixture performance was recognized early in the development of the mix design methods [20]. Various method of analyzing gradation were evaluated for an aggregate gradation "law" which could be used in selection of gradation for mixture design and one of them is 0.45 power chart.

Aggregate graduation is an important factor that influences the permanent deformation of HMA. One common way of characterizing aggregate gradation is by making a gradation plot on a 0.45 power chart [21], which also continue the maximum density line. The use of 0.45 power chart is to estimate available voids in the mineral aggregate (VMA) of the compacted mixture [20]. Increase VMA is obtained moving further from the maximum density line. Superpave has introduced a restriction zone superimposed on the maximum density between a line $2.36 \mathrm{~mm}$ and $0.3 \mathrm{~mm}$ sieve sizes, through which graduation are not recommended to pass [5]. It is believed that graduation passing through this zone can have low stability or resistance to rutting.

\section{Results and Analysis}

A summary of average resilient modulus (indirect tensile modulus test) obtained for SMA7-50, AC7-50, AC14-50, AC14-75, and AC20-75 Blow asphalt mixes are given in Table 2 to Table 6. From the data presented, it can be seen that AC20-75 Blow had high resilient modulus of $6794 \mathrm{MPa}$ (Table 6) as compared to other asphalt mixes. AC14-75 blow was the second in rank of $5959 \mathrm{MPa}$ (Table 5). This shows that the asphalt mixes are more stable and durable in pavement performance than others. However, SMA7-50, AC7-50, and AC14-50 Blow had a poor resilient modulus of 3600 MPa (Table 2), $4223 \mathrm{MPa}$ (Table 3), and $4921 \mathrm{MPa}$ (Table 4) in the given order, and none of these asphalt mixes tested exceeded the Australian standard limit. Mainroads Western Australia [22] and Austroad [12] stated that the indirect tensile test asphalt modulus used must exceed $5500 \mathrm{MPa}$.

The recovered horizontal strain and the resilient displacement deformation are given in Figure 2 to Figure 6. From the data demonstrated, it can be seen that the results are more or less similar for each asphalt mixes, and also within similar ranges of displacement of each pulse of each asphalt mixture. This shows that each one of them is within the required displacement and recovered strain standard. Austroads [12] described the standard requires that a total horizontal strain of between 30 to 70 micro strain (ms) has to achieve in a sample test results if the indirect tensile modulus test is used to evaluate the resilient modulus of asphalt mixes. This ensures that there is sufficient deformation for the linear variable displacement. It is clear that asphalt mix properties that tend to contribute low resilient moduli are low plasticity, low group index, high silt content, low specific gravity, and low group contents. Hicks and Monismith [23] discussed that resilient modulus of partially crushed aggregate decreased with an increase in fine contents, while the modulus increased for crushed aggregate with increase in fine content. Similarly, Thompson [24] mentioned that for given gradations, crushed material provide an increase in resilient modulus. 
Average dynamic creep for different types of asphalt mixes are shown in Figure 7. From the data presented, it can be seen that the asphalt mixes that exhibited high resilient modulus generally had high dynamic creep (compressive stress) and low minimum slope of strain. The average compressive stress for AC20-75 Blow asphalt mix was $200.2 \mathrm{kPa}$ while minimum slope of strain was $2.9 \mathrm{um} / \mathrm{m} / \mathrm{c}$. AC14-75 Blow asphalt mix had an average compressive stress of $199.7 \mathrm{kPa}$ and minimum slope of strain of $3.6 \mathrm{um} / \mathrm{m} / \mathrm{c}$, and made the asphalt mix in a second rank. The lower minimum slope at the accumulated strain at end of 5271 cycles indicated that high asphalt resistance to permanent deformation of asphalt mix. As regard the dynamic creep (compressive stress), asphalt mix that showed high value than other mixes is high resistance to rutting. However, SMA7-50, AC7-50, and AC14-50 Blow asphalt mix had high minimum slope of strain of 11.5, 5.9, and 10.3 $\mathrm{um} / \mathrm{m} / \mathrm{c}$, respectively. These indicated that low asphalt resistant to permanent deformation of asphalt pavement.

Average wheel tracking test for different types of asphalt mixes is shown in Figure 8. The analyses indicated that AC20-75 blow asphalt mix had low rut depth of $1.9 \mathrm{~mm}$ as compared to other asphalt mixes. AC14-75 blow was the second in rank with a rut depth of $2.4 \mathrm{~mm}$. This showed that these asphalt mixes are high rut resistance of asphalt mixture and less to pavement distress and asphalt fatigue cracking. However, the rut depth observed for SMA7-50 blow was $15 \mathrm{~mm}$ after 8, 452 cycles while $5 \mathrm{~mm}$ and $4.2 \mathrm{~mm}$ for AC7-50 blow and AC14-50 blow after 10,000 cycles, respectively. This indicated that SMA7-50 blow asphalt mix has high pavement distress and low rut resistance of asphalt mixture. There was also a sudden steep change in slope after 8,000 cycles for SMA7-50 blow. This may be attributed to the stripping of aggregate. No stripping was however, observed after 10, 000 cycles to other asphalt mixes.

A summary of aggregate gradations along with specific limit achieved for different types of asphalt mixes are shown in Table 7 and Figure 9. From the date presented, it can be seen that SMA7-50 and AC20-75 Blow asphalt mixes had high rank in aggregate gradation as compared to other asphalt mixes. This shows that the mixes are high stable in pavement performance, and also high resistance to rutting. However, AC7- 50, AC14-50, and AC14-75 have passed a restricted zone superimposed on the maximum density between a line $2.36 \mathrm{~mm}$ and $0.3 \mathrm{~mm}$ sieve size through gradation are not recommended to pass. This indicated that the mixes have low stability and low resistance to rutting. Kandhal and Mallick [21] noted that Superpave has introduced a restricted zone superimposed on the maximum density between a line $2.36 \mathrm{~mm}$ and $0.3 \mathrm{~mm}$ sieve sizes, through which gradation are not recommended to pass. It is believe that gradation passing through this zone can have low stability or resistance to rutting.

\section{Conclusions}

The pavement materials performance for strength and durability of flexible pavement was assessed and analyzed using the evaluation and validation of characterization methods for fatigue performance of different types of asphalt mixes for Western Australia road.

The comparison of the different types of asphalt mixes using a standard tests methods and techniques indicated that AC20-75 blow asphalt mix method is the most efficient and effective in all categories of engineering characterization and variability of asphalt pavement as compared to other asphalt mixes. AC14-75 blow asphalt mix was evaluated as the second in rank that increases the frictional contact between aggregate particle and overall stiffness and stability of the asphalt mixture.

In general, all the asphalt mixes that are used in this research study can strength and stable the mixture stiffness of asphalt that is notable. The modification effect rank can be described as AC2075 Blow > AC14-75 Blow > AC14-50 Blow > AC7-50 Blow > SMA7-50 Blow in this research. Aggregate particles that are in closed contact and interlocked with each other are able to resist traffic load and environmental factor with lower strain, and hence are stable, durable and stiffer. 


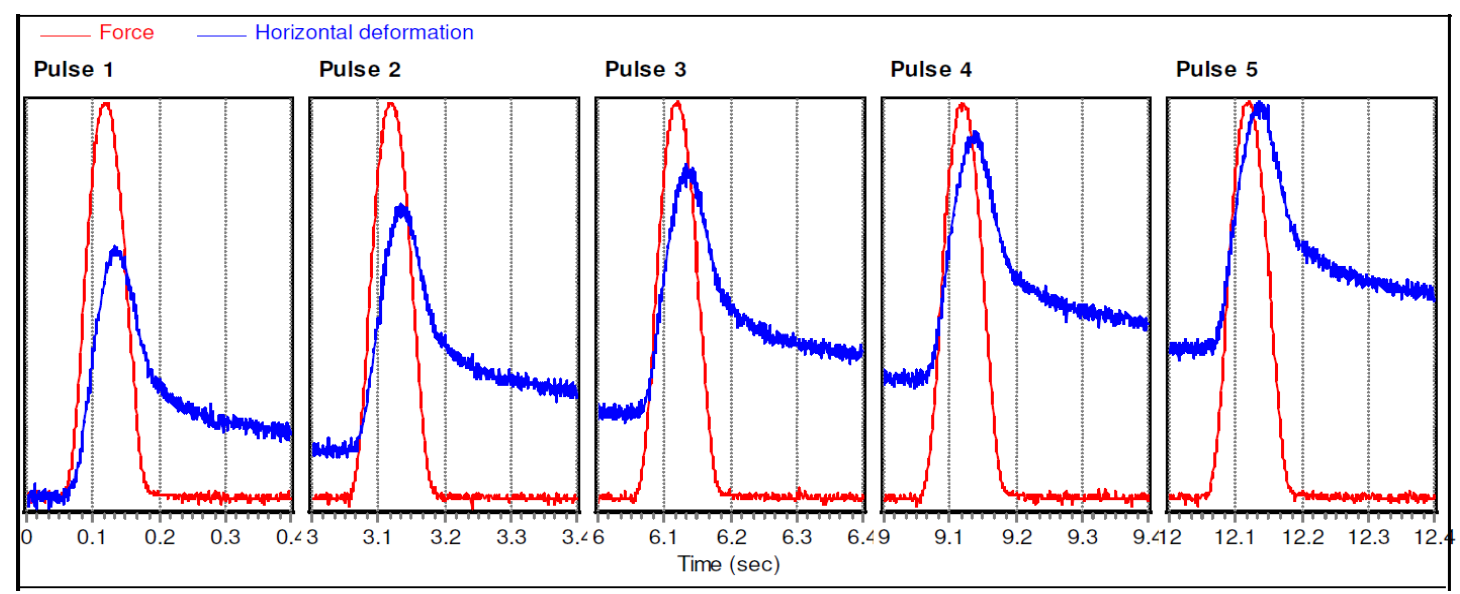

Figure 2: Indirect Tensile Modulus for SMA7-50 Blow Asphalt Mix

Table 2: Indirect Tensile Modulus Test for SMA7-50 Blow Asphalt Mix

\begin{tabular}{|c|c|c|c|c|c|c|c|c|}
\hline SMA7-50 Blow & $\begin{array}{c}\text { Pulse } \\
1\end{array}$ & $\begin{array}{c}\text { Pulse } \\
2\end{array}$ & $\begin{array}{c}\text { Pulse } \\
3\end{array}$ & $\begin{array}{c}\text { Pulse } \\
4\end{array}$ & $\begin{array}{c}\text { Pulse } \\
5\end{array}$ & Mean & Std.Dev & $\begin{array}{l}\text { CV } \\
(\%)\end{array}$ \\
\hline $\begin{array}{l}\text { Resilient modulus } \\
\text { (MPa) }\end{array}$ & 3711.0 & 3651.0 & 3590.0 & 3509.0 & 3537.0 & 3600.0 & 73.9 & 2.1 \\
\hline $\begin{array}{l}\text { Recovered horizontal } \\
\text { strain }(\mu \varepsilon)\end{array}$ & 51.0 & 51.8 & 53.0 & 54.1 & 53.8 & 52.7 & 1.2 & 2.2 \\
\hline $\begin{array}{l}\text { Peak load } \\
(\mathrm{N})\end{array}$ & 1841.3 & 1842.7 & 1852.5 & 1845.7 & 1852.0 & 1846.8 & 4.7 & 0.3 \\
\hline $\begin{array}{l}10 \% \text { to } 90 \% \text { rise } \\
\text { time (ms) }\end{array}$ & 36.0 & 35.0 & 36.0 & 36.0 & 37.0 & 36.0 & 0.6 & 1.8 \\
\hline $\begin{array}{l}\text { Load time } \\
(\mathrm{ms})\end{array}$ & 121.0 & 121.0 & 119.0 & 122.0 & 123.0 & 121.2 & 1.3 & 1.1 \\
\hline $\begin{array}{l}\text { Phase delay at } 90 \% \\
(\mathrm{~ms})\end{array}$ & 18.0 & 16.0 & 13.0 & 13.0 & 11.0 & 14.2 & 2.5 & 17.5 \\
\hline $\begin{array}{l}\text { Resilient horizontal } \\
\text { Deformation }(\mu \mathrm{m})\end{array}$ & 2.6 & 2.6 & 2.7 & 2.7 & 2.7 & 2.6 & 0.0 & 2.3 \\
\hline
\end{tabular}

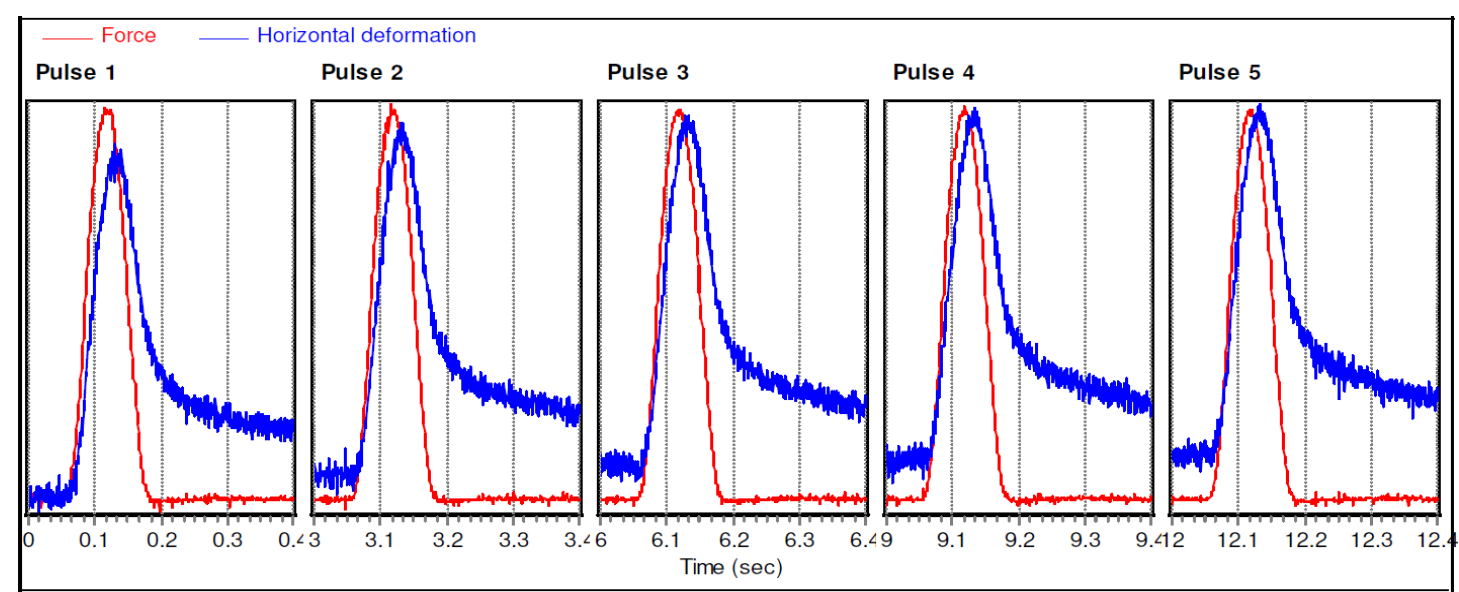

Figure 3: Indirect Tensile Modulus for AC7-50 Blow Asphalt Mix 
Table 3: Indirect Tensile Modulus Test for AC7-50 Blow Asphalt Mix

\begin{tabular}{|l|r|r|r|r|r|r|r|r|}
\hline AC7-50 Blow & $\begin{array}{r}\text { Pulse } \\
\mathbf{1}\end{array}$ & $\begin{array}{c}\text { Pulse } \\
\mathbf{2}\end{array}$ & $\begin{array}{c}\text { Pulse } \\
\mathbf{3}\end{array}$ & $\begin{array}{c}\text { Pulse } \\
\mathbf{4}\end{array}$ & $\begin{array}{c}\text { Pulse } \\
\mathbf{5}\end{array}$ & Mean & Std.Dev & $\begin{array}{r}\text { CV } \\
(\%)\end{array}$ \\
\hline $\begin{array}{l}\text { Resilient modulus } \\
(\mathbf{M P a})\end{array}$ & 4377.0 & 4283.0 & 4152.0 & 4172.0 & 4133.0 & 4223.0 & 92.9 & 2.2 \\
\hline $\begin{array}{l}\text { Recovered horizontal } \\
\text { strain }(\boldsymbol{\mu} \boldsymbol{)})\end{array}$ & 50.0 & 51.5 & 52.5 & 52.7 & 52.7 & 51.9 & 1.0 & 2.0 \\
\hline $\begin{array}{l}\text { Peak load } \\
(\mathbf{N})\end{array}$ & 2181.2 & 2137.2 & 2109.9 & 2129.4 & 2107.0 & 2120.3 & 11.5 & 0.5 \\
\hline $\begin{array}{l}\text { 10\% to 90\% rise time } \\
(\mathbf{m s})\end{array}$ & 36.0 & 36.0 & 36.0 & 38.0 & 36.0 & 36.4 & 0.8 & 2.2 \\
\hline $\begin{array}{l}\text { Load time } \\
(\mathbf{m s})\end{array}$ & 120.0 & 118.0 & 116.0 & 118.0 & 118.0 & 118.0 & 1.3 & 1.1 \\
\hline $\begin{array}{l}\text { Phase delay at 90\% } \\
(\mathbf{m s})\end{array}$ & 26.0 & 18.0 & 15.0 & 13.0 & 16.0 & 17.6 & 4.5 & 25.6 \\
\hline $\begin{array}{l}\text { Resilient horizontal } \\
\text { Deformation }(\boldsymbol{\mu m})\end{array}$ & 2.5 & 2.4 & 2.6 & 2.6 & 2.6 & 2.6 & 0.1 & 2.3 \\
\hline
\end{tabular}

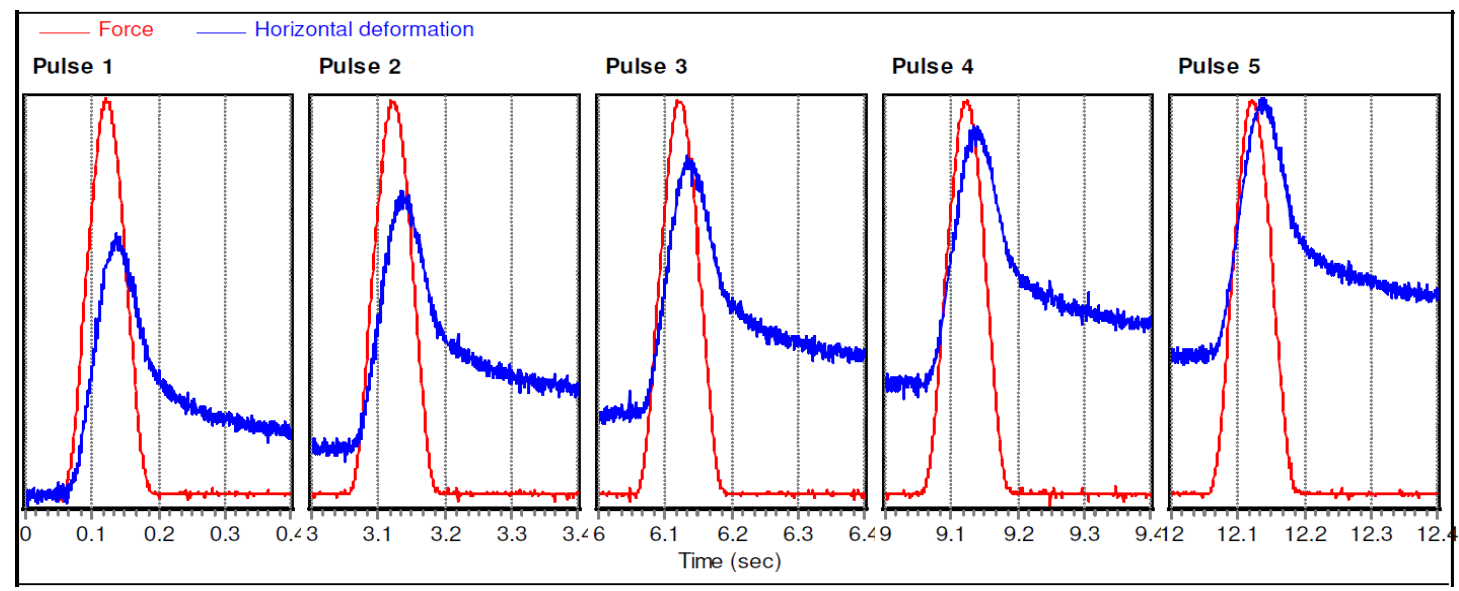

Figure 4: Indirect Tensile Modulus for AC14-50 Blow Asphalt Mix

Table 4: Indirect Tensile Modulus Test for AC14-50 Blow Asphalt Mix

\begin{tabular}{|c|c|c|c|c|c|c|c|c|}
\hline AC14-50 Blow & $\begin{array}{c}\text { Pulse } \\
1\end{array}$ & $\begin{array}{c}\text { Pulse } \\
2\end{array}$ & $\begin{array}{c}\text { Pulse } \\
3\end{array}$ & $\begin{array}{c}\text { Pulse } \\
4\end{array}$ & $\begin{array}{c}\text { Pulse } \\
5\end{array}$ & Mean & Std.Dev & $\begin{array}{l}\mathrm{CV} \\
(\%)\end{array}$ \\
\hline $\begin{array}{l}\text { Resilient modulus } \\
\text { (MPa) }\end{array}$ & 5158.0 & 4962.0 & 4842.0 & 4845.0 & 4745.0 & 4921.0 & 130.5 & 2.7 \\
\hline $\begin{array}{l}\text { Recovered horizontal } \\
\text { strain }(\mu \varepsilon)\end{array}$ & 51.7 & 53.5 & 54.8 & 54.8 & 55.3 & 54.0 & 1.3 & 2.5 \\
\hline $\begin{array}{l}\text { Peak load } \\
(\mathrm{N})\end{array}$ & 2584.6 & 2576.3 & 2575.6 & 2577.8 & 2573.4 & 2577.8 & 3.7 & 0.1 \\
\hline $\begin{array}{l}10 \% \text { to } 90 \% \text { rise time } \\
(\mathrm{ms})\end{array}$ & 41.0 & 40.0 & 41.0 & 39.0 & 40.0 & 40.2 & 0.8 & 1.9 \\
\hline $\begin{array}{l}\text { Load time } \\
\text { (ms) }\end{array}$ & 127.0 & 123.0 & 123.0 & 122.0 & 123.0 & 123.6 & 1.7 & 1.4 \\
\hline $\begin{array}{l}\text { Phase delay at } 90 \% \\
\text { (ms) }\end{array}$ & 17.0 & 12.0 & 12.0 & 9.0 & 11.0 & 12.2 & 2.6 & 21.6 \\
\hline $\begin{array}{l}\text { Resilient horizontal } \\
\text { Deformation }(\mu \mathrm{m})\end{array}$ & 2.6 & 2.7 & 2.8 & 2.8 & 2.7 & 2.7 & 0.1 & 2.7 \\
\hline
\end{tabular}




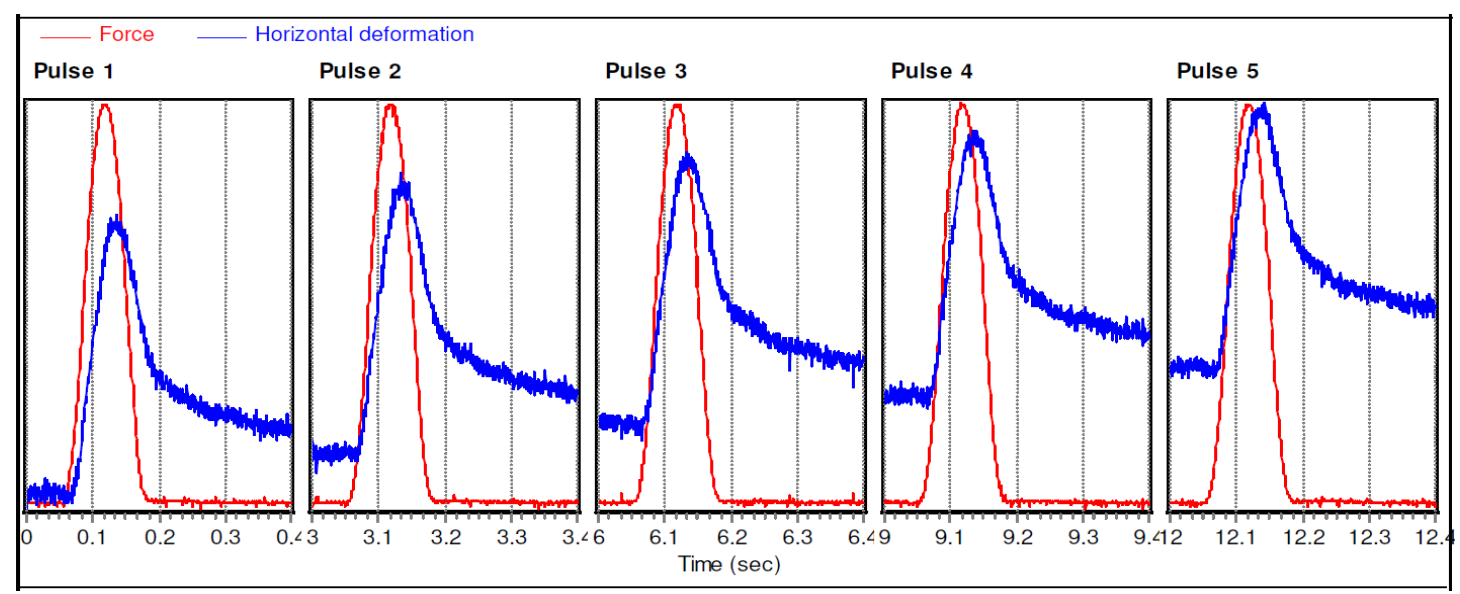

Figure 5: Indirect Tensile Modulus for AC14-75 Blow Asphalt Mix

Table 5: Indirect Tensile Modulus Test for AC14-75 Blow Asphalt Mix

\begin{tabular}{|c|c|c|c|c|c|c|c|c|}
\hline AC14-75 Blow & $\begin{array}{c}\text { Pulse } \\
1\end{array}$ & $\begin{array}{c}\text { Pulse } \\
2\end{array}$ & $\begin{array}{c}\text { Pulse } \\
3\end{array}$ & $\begin{array}{c}\text { Pulse } \\
4\end{array}$ & $\begin{array}{c}\text { Pulse } \\
5\end{array}$ & Mean & Std.Dev & $\begin{array}{l}\text { CV } \\
(\%)\end{array}$ \\
\hline $\begin{array}{l}\text { Resilient modulus } \\
\text { (MPa) }\end{array}$ & 6016.0 & 5776.0 & 5912.0 & 6107.0 & 5983.0 & 5959.0 & 110.8 & 1.9 \\
\hline $\begin{array}{l}\text { Recovered horizontal } \\
\text { strain }(\mu \varepsilon)\end{array}$ & 47.7 & 49.7 & 48.6 & 47.2 & 48.0 & 48.3 & 0.9 & 1.8 \\
\hline $\begin{array}{l}\text { Peak load } \\
(\mathbf{N})\end{array}$ & 2926.9 & 2830.3 & 2832.7 & 2838.1 & 2831.3 & 2831.8 & 3.7 & 0.1 \\
\hline $\begin{array}{l}10 \% \text { to } 90 \% \text { rise time } \\
(\mathrm{ms})\end{array}$ & 37.0 & 37.0 & 37.0 & 37.0 & 38.0 & 37.2 & 0.4 & 1.1 \\
\hline $\begin{array}{l}\text { Load time } \\
(\mathrm{ms})\end{array}$ & 119.0 & 121.0 & 119.0 & 119.0 & 121.0 & 119.9 & 1.0 & 0.8 \\
\hline $\begin{array}{l}\text { Phase delay at } 90 \% \\
(\mathrm{~ms})\end{array}$ & 16.0 & 21.0 & 17.0 & 13.0 & 15.0 & 16.4 & 2.7 & 16.2 \\
\hline $\begin{array}{l}\text { Resilient horizontal } \\
\text { Deformation }(\mu \mathrm{m})\end{array}$ & 2.4 & 2.5 & 2.4 & 2.4 & 2.4 & 2.4 & 0.1 & 12.8 \\
\hline
\end{tabular}

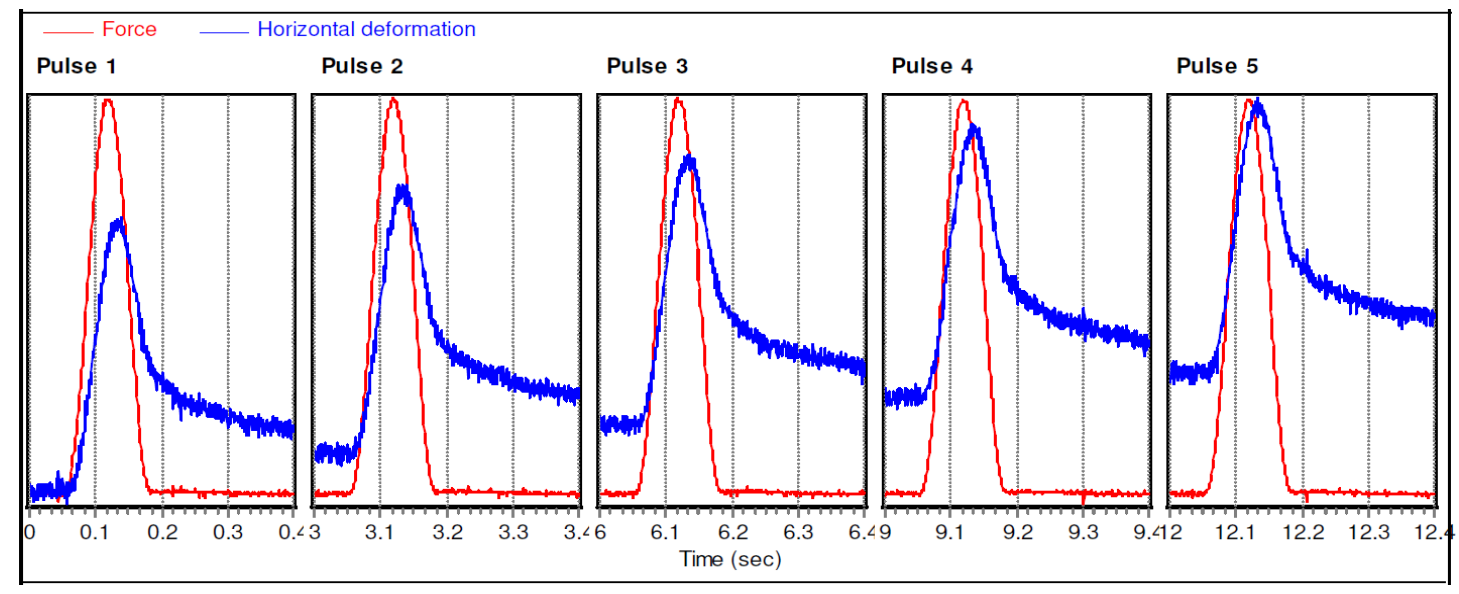

Figure 6: Indirect Tensile Modulus for AC20-75 Blow Asphalt Mix 
Table 6: Indirect Tensile Modulus for AC20-75 Blow Asphalt Mix

\begin{tabular}{|c|c|c|c|c|c|c|c|c|}
\hline AC20-75 Blow & $\begin{array}{c}\text { Pulse } \\
1\end{array}$ & $\begin{array}{c}\text { Pulse } \\
2\end{array}$ & $\begin{array}{c}\text { Pulse } \\
3 \\
\end{array}$ & $\begin{array}{c}\text { Pulse } \\
4 \\
\end{array}$ & $\begin{array}{c}\text { Pulse } \\
5\end{array}$ & Mean & Std.Dev & $\begin{array}{l}\text { CV } \\
(\%) \\
\end{array}$ \\
\hline $\begin{array}{l}\text { Resilient modulus } \\
\text { (MPa) }\end{array}$ & 7047.0 & 6931.0 & 6786.0 & 6638.0 & 6567.0 & 6794.0 & 177.8 & 2.6 \\
\hline $\begin{array}{l}\text { Recovered horizontal } \\
\text { strain }(\mu \varepsilon)\end{array}$ & 49.3 & 50.3 & 51.3 & 52.1 & 52.8 & 51.2 & 1.3 & 2.5 \\
\hline $\begin{array}{l}\text { Peak load } \\
(\mathrm{N})\end{array}$ & 3300.1 & 3314.3 & 3309.4 & 3288.4 & 3297.2 & 3301.9 & 9.1 & 0.3 \\
\hline $\begin{array}{l}10 \% \text { to } 90 \% \text { rise time } \\
(\mathrm{ms})\end{array}$ & 39.0 & 39.0 & 39.0 & 39.0 & 39.0 & 39.0 & 0.0 & 0.0 \\
\hline $\begin{array}{l}\text { Load time } \\
(\mathrm{ms})\end{array}$ & 120.0 & 120.0 & 121.0 & 118.0 & 120.0 & 119.8 & 1.0 & 0.8 \\
\hline $\begin{array}{l}\text { Phase delay at } 90 \% \\
(\mathrm{~ms})\end{array}$ & 15.0 & 12.0 & 11.0 & 11.0 & 10.0 & 11.8 & 1.7 & 14.6 \\
\hline $\begin{array}{l}\text { Resilient horizontal } \\
\text { Deformation }(\mu \mathrm{m})\end{array}$ & 2.5 & 2.3 & 2.4 & 2.5 & 2.5 & 2.4 & 0.1 & 3.0 \\
\hline
\end{tabular}

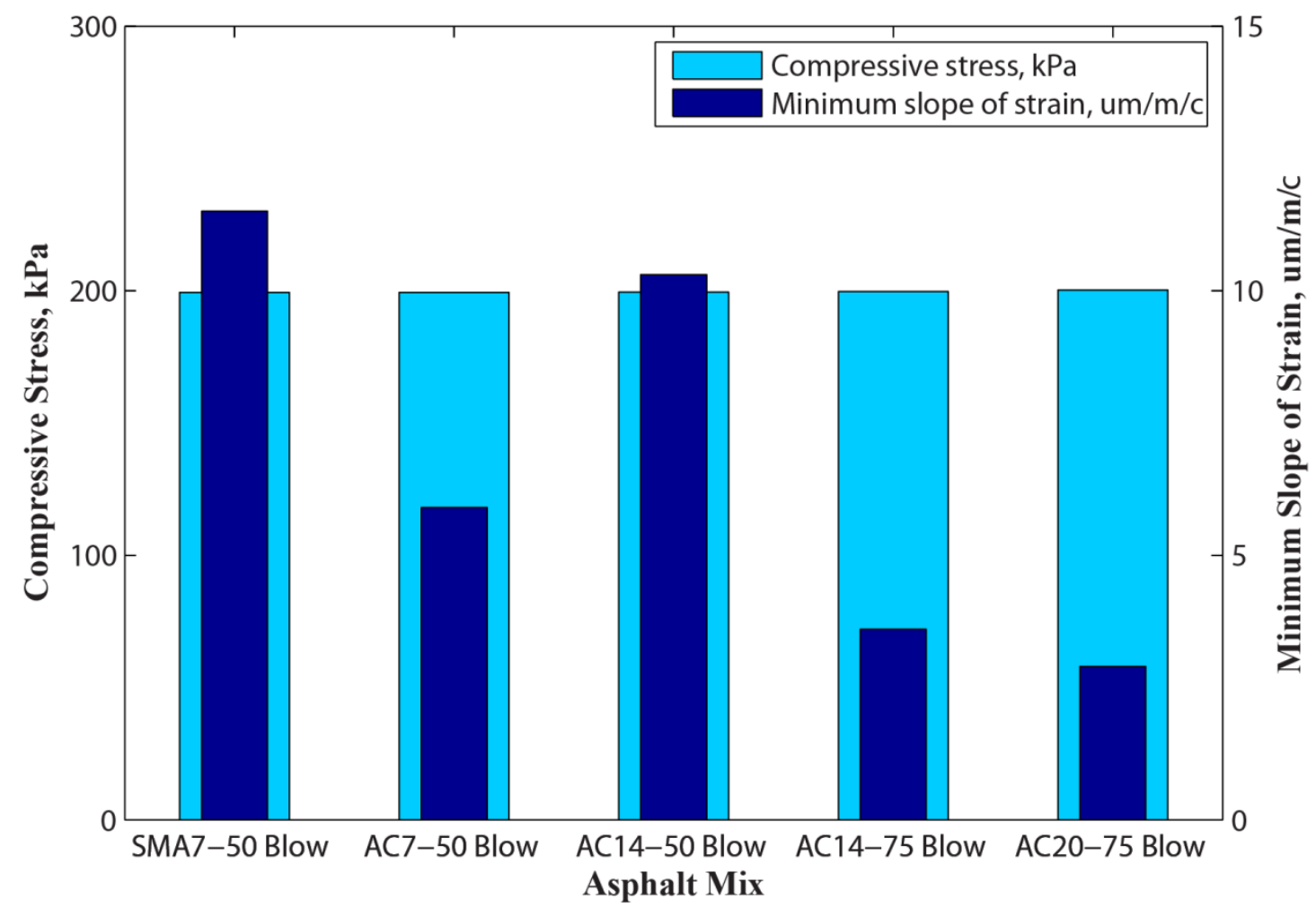

Figure 7: Dynamic Creep (Average Compressive Stress and Minimum of Slope of Strain) of Different Types of Asphalt Mixes 


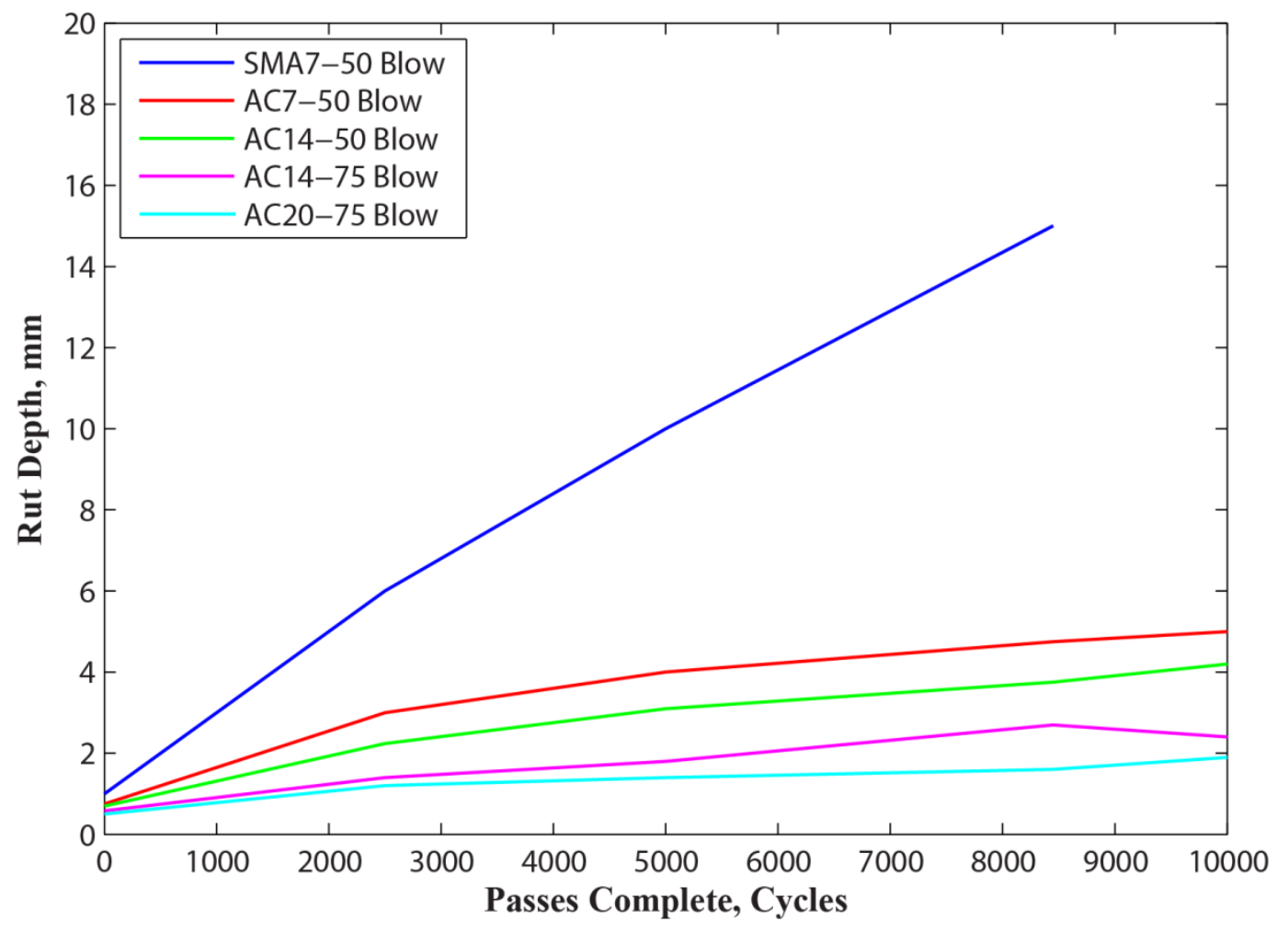

Figure 8: Average wheel tracking tests for different types of asphalt mixes

Table 7: Aggregate Gradation and Their Proportions Along With Specific Limits of Different Types of Asphalt Mixes

\begin{tabular}{|c|c|c|c|c|c|c|}
\hline $\begin{array}{c}\text { Sieve Size } \\
(\mathbf{m m})\end{array}$ & \multicolumn{5}{|c|}{ Percent sieve passing by weight } & $\begin{array}{c}\text { Austroad } \\
\text { Spec. limits }\end{array}$ \\
\cline { 2 - 6 } & $\begin{array}{c}\text { SMA7-50 } \\
\text { Blow }\end{array}$ & $\begin{array}{c}\text { AC7-50 } \\
\text { Blow }\end{array}$ & $\begin{array}{c}\text { AC14-50 } \\
\text { Blow }\end{array}$ & $\begin{array}{c}\text { AC14-75 } \\
\text { Blow }\end{array}$ & $\begin{array}{c}\text { AC20-75 } \\
\text { Blow }\end{array}$ & \\
\hline 26.5 & 100 & 100 & 100 & 100 & 100 & 100 \\
\hline 19 & 100 & 100 & 100 & 100 & 98.2 & 100 \\
\hline 13.2 & 100 & 100 & 98.1 & 96.9 & 78.3 & 100 \\
\hline 9.5 & 100 & 100 & 80.1 & 80.8 & 61.2 & 100 \\
\hline 6.7 & 97.6 & 98.3 & 63.5 & 71.1 & 50.9 & $85-100$ \\
\hline 4.75 & 35 & 83.1 & 52.8 & 57.1 & 45 & $30-63$ \\
\hline 2.36 & 22.5 & 57.6 & 39 & 38.8 & 35.8 & $20-35$ \\
\hline 1.18 & 18.5 & 41.89 & 28.3 & 27.01 & 25.54 & $16-28$ \\
\hline 0.6 & 15.75 & 31.4 & 20.07 & 18.56 & 17.95 & $14-24$ \\
\hline 0.3 & 13.06 & 18.37 & 12.96 & 11.58 & 11.95 & $12-20$ \\
\hline 0.15 & 10.83 & 8.59 & 7.74 & 6.57 & 6.34 & $10-16$ \\
\hline 0.075 & 9.01 & 4.76 & 4.57 & 3.65 & 3.91 & $8-12$ \\
\hline
\end{tabular}




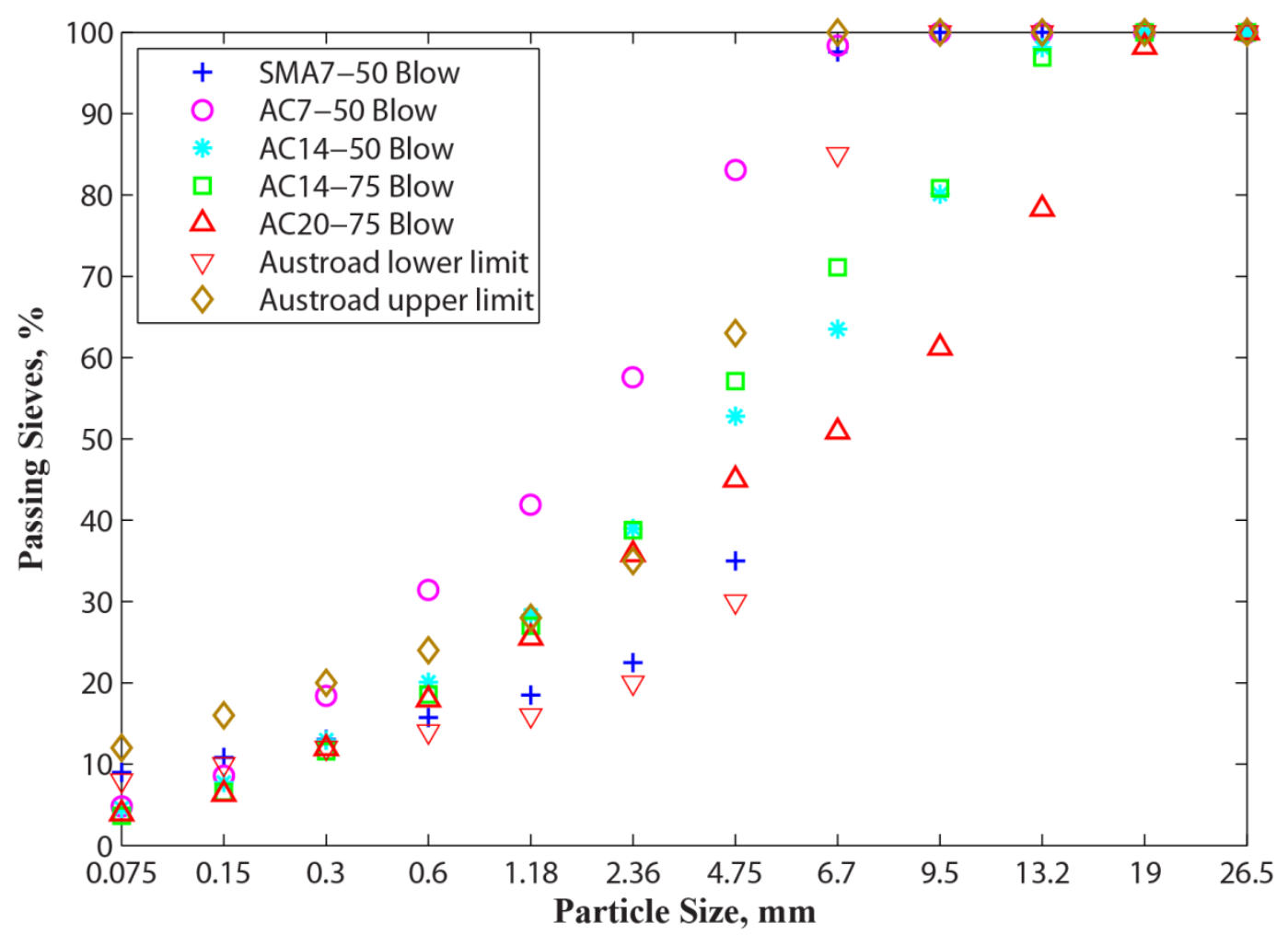

Figure 9: Aggregate Grading Curve for Different Types of Asphalt Mixes

\section{Acknowledgement}

The financial support for this study was provided by the research project 2011/0006, entitled "Characteristics of Western Australia Asphalt Mixes" sponsored by Australia Postgraduate Awards (APA), Curtin Research Scholarship (CRS) and the Mainroads Western Australia.

The options, findings and conclusions expressed in this publication are not necessary those of Australia Postgraduate Awards, Curtin Research Scholarship or Mainroads Western Australia.

\section{References}

[1] P. Baburamani, Asphalt fatigue life predication models - a literature review, in: Research Report ARR, ARRB Transport Research Ltd, Vermont South, Victoria, 1999, pp. 1-40.

[2] B.A. Chadbourn, J.A. Luoma, D.E. Newcomb, V.R. Voller, Consideration of hot-mix asphalt thermal properties during compaction, in: D.S. Decker (Ed.) Quality management of hot-mix asphalt, ASTM STP 1299, American Society for Testing and Materials, Minneapolis, Minnesota, 1996, pp. 127-135.

[3] G.M. Rowe, Performance of asphalt mixtures in the trapezoidal fatigue test, Journal of the Association of Asphalt Paving Technologist, 63 (1993) 344-384.

[4] S.F. Said, Fatigue characteristics of asphalt concrete mistures, in, Swedish Road and Traffic Research Institute Report 583A. , 1988, pp. 1-66.

[5] Strategic Highway Research Program, Standard method of test for determining the fatigue life of compacted bituminous mixtures subjects to repeated flexural bending M-009, in: E.T. Harrigan, R.B. Leah, R.B. Youtchef (Eds.) The Superpave mix design system manual of specifications, Test Methods and Practice, SHRP A 379, Strategic Highway Research Program, Washington, D.C., 1994a, pp. 1-253.

[6] The Asphalt Institute, Thickness design - asphalt pavements for highways and streets, Mmanual series No. 1 (MS-1), The Asphalt Institute, College Park, Maryland, USA, 1998. 
[7] American Concrete Institute Committee, Aggregates for concrete, in: W.R. Malisch (Ed.) Materials for concrete construction, American Concrete Institute, Farmington Hills, MI, USA, 2007, pp. E1-99.

[8] E.R. Brown, P.S. Kandhal, J. Zhang, Performance testing for hot-mix asphalt, in: C. Cullather, J. Correro, J. Weeks, J. Awan (Eds.) Transportation Research Circular E-C068: New Simple Performance Tests for Asphalt Mixes, Transportation Research Board, Washington, DC, 2004, pp. 85-106.

[9] Main Roads Western Australia, Annual Report, in, Main Road Western Australia, Perth, WA, Australia, 2007, pp. 1-134.

[10] Austroads, A guide to the structureal design of road pavements: pavement materials, Austroads, Sydney, Australia, 1992.

[11] Austroads, Asphalt characterization of pavement design, in, Austroads, Sydney, Australia, 2006, pp. 1-47.

[12] Austroads, Testing asphalt in accordance with the Austroads mix design procedures, in: A. Alderson (Ed.), Austroads, Sydney, Australia., 2008, pp. 1-71.

[13] Federal Highway Administration, Study of LTPP laboratory resilient modulus test data and response characteristic: final report, in, Federal Highway Transportation, U.S. Department of Transportation, Mclean, VA, USA, 2002, pp. 1-161.

[14] American Association of State Highway and Transportation Officials, AASHTO Guide for design of pavement structures, American Association of State Highway and Transportation Officials, Washington, DC, USA, 1993.

[15] Z.A. Khan, H.I. Al-Abdul Wahab, I. Asi, R. Ramadhan, Comparative study of asphalt concrete laboratory compaction methods to simulate field compaction, Construction and Building Materials, 12 (1998) 373-384.

[16] R.B. Mallick, R. Ahlrich, E.R. Brown, Potential of dynamic creep to predict rutting, in: G.A. Huber, D.S. Decker (Eds.) Engineering properties of asphalt mixtures and the relationship to their performance, ASTM STP 1265 American Society of Testing and Materials, Philadelphia, 1995, pp. 194-212.

[17] A.J. Alderson, Development of a wheel tracking test for Australia, in: Focussing on performance: AAPA pavements industry conference, Australian Asphalt Pavement Association, Surfers Paradise, Queenland, Australia, 1998.

[18] J.W.H. Olive, A.J. Alderson, The effect of air void content on resilient modulus, dynamic creep and wheel tracking results, in, ARRB Transport Research Ltd, Australia, 1995a.

[19] W.H. Goetz, The Evolution of asphalt concrete mix design, in: W.G. Jr (Ed.) Asphalt concrete mix design: development of more rational approaches, ASTM STP 1041, American Society of Testing and Materials, Philadelphia, 1989, pp. 5-14.

[20] G.A. Huber, T.S. Shuler, Providing sufficient void space for asphalt cement: relationship of mineral aggregate voids and aggregate gradation, in: R.C. Meininger (Ed.) Effect of aggregate and mineral fillers on asphalt mixture performance, ASTM STP 1147, American Society of Testing and Materials, Philadelphia, 1992, pp. 225-251.

[21] P.S. Kandhal, R.B. Mallick, Effect of mix gradation on rutting potential of dense-graded asphalt mixtures, Transportation Research Record: Journal of the Transportation Research Board, 1767 (2001) 146-151.

[22] Main roads Western Australia, Procedure for the design of flexiable pavement, in: Engineering road note 9, TRIM 05/5236, Main Road Western Australia, Perth, Western Australia, 2010, pp. 130 .

[23] G.R. Hicks, C.L. Monismith, Factor influencing the resilient response of granular materials, in: Highway Research Record 345, National Research Council, Washington, DC, 1981, pp. 15-31.

[24] M.R. Thompston, Factors affecting the resilient modulus of soils and granular materials, Workshop on resilient modulus testing, in, Oregon State University, Corvallis, Oregon, 1989. 